\title{
Imagens sedutoras da modernidade urbana: reflexões sobre a construção de um novo padrão de visualidade urbana nas revistas ilustradas na década de 1950
}

Charles Monteiro ${ }^{1}$

PUC-RS

\section{RESUMO}

Este artigo contém resultados parciais de pesquisa em andamento sobre a construção de uma nova visualidade urbana na década de 1950 nas revistas ilustradas brasileiras, visando problematizar a forma como esses veículos de comunicação geriram e deram a ver através da fotografia a imagem de um país em transformação e em acelerado processo de urbanização. Inicialmente, abordamse questões gerais sobre a forma de edição das revistas ilustradas e o formato das fotorreportagens para, posteriormente, apresentar-se um estudo de caso sobre a Revista do Globo nos anos 50.

Palavras-chave: Imagens da cidade; História e fotografia; Cultura visual.

\section{ABSTRACT}

This paper presents partial results of an ongoing research on the creation of a new urban perception in the 1950s illustrated magazines in Brazil. It aims to cast doubt on the way these means of communication managed and worked in the image of a country at a fast pace of change and urban development process through photographs. Firstly, a wide range of matters concerning the way these magazines were edited alongside the layout of the photos in the articles are discussed. After that, a case study about the Revista do Globo in the 50 s is presented.

Keywords: City images; History and photograph; Visual culture.

O objetivo deste texto é compreender a construção de uma nova visualidade urbana nas revistas ilustradas na década de 1950, visando problematizar a forma como esses veículos de comunicação deram a ver através de fotorreportagens a imagem de um país em acelerado processo de urbanização. Inicialmente, abordam-se questões gerais sobre a edição das revistas ilustradas e o formato padrão das fotorreportagens para, posteriormente, apresentar-se um pequeno estudo de caso sobre a Revista do Globo nos anos 50. 
Algumas questões orientadoras podem direcionar o percurso de reflexão deste texto: Qual a especificidade da leitura e interpretação da fotografia de imprensa e, em especial, da fotorreportagem? Qual a relação entre elementos textuais (título, subtítulos, legenda da foto, texto informativo) e as imagens fotográficas nas fotorreportagens sobre cidades nas revistas ilustradas?

O que é uma fotografia? É uma imagem técnica de natureza híbrida, em parte produzida por processos físico-químicos e em parte produzida pela mão do homem com auxílio de um aparelho ótico. ${ }^{2}$ Em sua produção entram as concepções técnicas, políticas, sociais, culturais e estéticas do fotógrafo e da sociedade à qual ele pertence. A fotografia é uma imagem ambígua e polissêmica, passível de múltiplas interpretações de acordo com o meio que a veicula, seu intérprete, os contextos e os tempos de sua produção e recepção.

A fotografia é também uma redução ou recorte do real. Primeiramente, um corte no fluxo do tempo, o congelamento de um instante separado da sucessão dos acontecimentos. Em segundo lugar, ela é um fragmento escolhido pelo fotógrafo pela seleção do tema, dos sujeitos, do entorno, dos objetos, do enquadramento, do sentido, do foco, da luminosidade, do formato e do equipamento, por exemplo. Em terceiro lugar, transforma o tridimensional em bidimensional, reduz a gama das cores e simula a profundidade do campo de visão. Ela é também uma convenção do olhar herdada do Renascimento e da pintura e reelaborada pela técnica, que é necessário apreender a ver. A câmara fotográfica capta às vezes mais e às vezes menos do que o nosso olho pode ver.

Segundo Philippe Dubois, ${ }^{3}$ a fotografia se distingue de outros sistemas de representação como a pintura e o desenho (dos ícones), bem como dos sistemas propriamente lingüísticos (dos símbolos) enquanto se aparenta muito com o dos signos, como, por exemplo, a fumaça (índice do fogo), a sombra (alcance), a poeira (depósito do tempo), a cicatriz (marca de um ferimento) e as ruínas (vestígios de algo que esteve ali).

Para esse autor, a fotografia é um índice. Nem 'espelho do real', como se pretendeu no final do século XIX no senso comum e muitas vezes na imprensa, nem uma 'transformação do real', entendida como redução e distorção desse real, como se denunciou no século XX a falsa neutralidade da mensagem fotográfica. A fotografia guarda um elo físico com o seu referente. Ela é uma marca deixada pelo fluxo luminoso emitido ou refletido por um corpo físico (pessoa ou objeto) sobre uma superfície sensível (placa de metal, papel, vidro, ou filme), como afirma Jean-Marie Schaeffer em $A$ imagem precária. ${ }^{4}$

Para Roland Barthes, a fotografia jornalística é uma mensagem constituída por: 
uma fonte emissora, um canal de transmissão e um meio receptor. A fonte emissora é a redação do jornal, seu grupo de técnicos, dos quais alguns fazem a foto, outros selecionam, a compõem e retocam e outros, enfim, a intitulam, a legendam, a comentam. O meio receptor é o público que lê o jornal. E o canal de transmissão é o próprio jornal, ou, mais exatamente, um complexo de mensagens concorrentes cujo centro é a fotografia; os complementos que a circundam são o texto, o título, a legenda, a diagramação e, de maneira mais abstrata não menos 'informante', o próprio nome do jornal...

Pode-se substituir 'jornal' por 'revista ilustrada' e a proposta de Barthes continua valendo para pensar a fotografia de imprensa de forma mais ampla. Logo, torna-se necessário conhecer e decifrar as convenções dessa linguagem. Para isso é preciso um aprendizado desses códigos e uma cuidadosa discussão teórico-metodológica, que permita pensar a dimensão propriamente visual do real visando integrá-la à pesquisa histórica.

Mas qual o contexto da década de 1950, no qual se pretende analisar as imagens fotográficas nas revistas ilustradas?

Nos anos 50 ocorreu no Brasil o que alguns economistas chamaram de 'revolução verde', ocasionada pela introdução de novas técnicas agrícolas e pelo desenvolvimento capitalista no campo, provocando a expulsão de um vasto contingente de trabalhadores para os centros urbanos.

O período foi marcado, também, por migrações em massa das regiões brasileiras agrícolas para os estados mais industrializados e para as novas frentes de colonização: do Nordeste para o Sudeste e o Centro-Oeste, e do Sul para o Centro-Oeste. O deslocamento de populações do Nordeste para a construção de Brasília é um exemplo marcante desse fenômeno de redistribuição da população no território nacional.

Os trabalhadores do campo não estavam amparados na nova legislação do trabalho e não possuíam uma série de direitos conquistados pelos trabalhadores urbanos sindicalizados e politicamente mobilizados dentro do jogo político dos partidos criados no período imediatamente posterior à Segunda Guerra Mundial e ao Estado Novo.

A cidade afigurava-se para essa população flagelada pelas sucessivas secas, sem direitos trabalhistas e submetidas ao poder dos latifundiários, como uma nova terra de promissão. Esse contingente populacional foi atraído pela promessa de empregos na indústria em crescimento, de amparo da previdência social, de educação para os filhos e uma série de outras oportunidades de trabalho informal e de lazer. 
Tanto a política populista-nacionalista de Vargas como o discurso desenvolvimentista de Juscelino Kubitschek baseavam-se no fenômeno da expansão do eleitorado urbano e na organização de partidos de massa.

O espaço urbano passava por um processo de verticalização e periferização. As capitais cresciam verticalmente nas suas áreas centrais com a construção de grandes prédios de estilo arquitetônico modernista, movimento que mobilizou arquitetos e urbanistas na reinvenção da arquitetura brasileira, movidos pela utopia de remodelar as velhas cidades transformando-as em cidades modernas, planejadas, funcionais e belas para o desfrute das elites e das camadas médias urbanas.

Porém, foi nas periferias das grandes cidades que se estabeleceu o contingente populacional expulso do campo e sem qualificação profissional, que vinha trabalhar na construção civil, nas fábricas, no pequeno comércio, nos transportes, nos serviços domésticos, na limpeza urbana e numa série de trabalhos eventuais e não-formais.

Em São Paulo e no Rio de Janeiro foram construídos conjuntos habitacionais como as "Cidades de Deus" para receber esse contingente populacional, procurando ordená-lo e enquadrá-lo na esfera produtiva, mas a única infra-estrutura neles existente consistia em água e transporte público. ${ }^{6}$ Foi justamente a implementação dos serviços de transportes urbanos por ônibus que permitiu a expansão e a periferização da cidade geradora da segregação da classe trabalhadora no espaço urbano.

Em Porto Alegre, em 1959, uma lei municipal definiu os nomes e os limites de 58 bairros, enquanto na periferia 40 vilas de casas autoconstruídas não paravam de crescer, como a Vila Caiu do Céu. O problema da moradia gerou a criação do Departamento da Casa Popular (futuro DEMHAB), pois os recém-construídos conjuntos habitacionais como a Vila IAPI e a Vila dos Comerciários eram dirigidos apenas a uma elite de trabalhadores que pertenciam aos Institutos de Previdência.

O período também foi marcado pela modernização da grande imprensa nos principais centros urbanos (especialmente nas capitais), dominada por algumas famílias ricas, proprietárias de jornais e rádios, que passaram a monopolizar o setor de comunicação.

As inovações se concentravam em alguns novos jornais, como a Última Hora, de Samuel Wainer, ou o suplemento cultural do Jornal do Brasil, mas, principalmente, na modernização e expansão das revistas ilustradas como $O$ Cruzeiro, Revista do Globo e Manchete, que aumentaram suas tiragens e se afirmaram como empresas capitalistas voltadas para a venda de informação e es- 
paço publicitário. A expansão do espaço destinado à publicidade e aos classificados e a ampliação do número de leitores favoreceram uma série de inovações na editoração e na diagramação desses periódicos, permitindo a utilização cada vez mais freqüente de fotografias. Porém, esses veículos não estavam totalmente livres do jogo político partidário e da dependência da propaganda institucional de governos estadual e federal.

As revistas ilustradas formavam um segmento diferenciado, visando um público de maior poder aquisitivo e construindo as matérias sob um ângulo novo. As revistas ilustradas semanais e quinzenais, como no caso da Revista do Globo, lidavam com a temporalidade de modo diferente dos jornais cotidianos. Enquanto o jornal trabalha com o imediato, as revistas trabalham com a atualidade oferecendo uma nova abordagem dos acontecimentos.?

Elas desempenham toda uma nova pedagogia social sobre as elites vindas do campo, as camadas médias provenientes das pequenas cidades do interior e os próprios habitantes das capitais em processo de expansão e transformação do espaço urbano. A revista O Cruzeiro, a Revista do Globo e a Manchete se destacavam como os veículos de comunicação impressa mais modernos, no sentido de construírem um novo tipo de reportagem e de narrativa baseada no uso da fotografia. Algo que vinha sendo feito na Europa e nos Estados Unidos desde os anos 20, mas que atinge a sua maturidade no Brasil nos anos $50 .{ }^{8}$

As revistas eram meios híbridos, que mesclavam uma variedade de temas - política nacional e internacional, artes, vida social, cotidiano, esportes, variedades e publicidade - buscando equilibrar informação, formação de opinião e entretenimento. ${ }^{9}$ Elas procuravam tratar de assuntos polêmicos para mobilizar a atenção do público leitor. As revistas trabalhavam também com binômios ou polaridades como 'nós e os outros', 10 'presente e passado', 'tradição e modernidade', freqüentemente propondo uma abordagem sensacionalista dos acontecimentos.

As fotorreportagens construíram uma imagem desses outros que chegam à cidade e uma imagem da cidade em processo de mudança para o consumo das elites e camadas médias. ${ }^{11}$ As cidades tornavam-se cada vez maiores e inabarcáveis pelo olhar, necessitando assim de um veículo de mediação para a gestão das mudanças na paisagem urbana em um tempo acelerado. Daí a importância de as revistas ilustradas veicularem fotos aéreas e panorâmicas, que ajudavam os habitantes das grandes cidades a elaborarem o processo de expansão urbano.

A fotografia permitia também congelar fragmentos de temporalidade e 
condensar a nova imagem da cidade em processo de mutação. Ou seja, a fotografia e, em especial, as fotorreportagens permitem através de um 'dar a ver a cidade’ uma educação do olhar e a elaboração de uma nova estética nesse processo de expansão horizontal e vertical urbana. Mas também difundiram uma nova cultura urbana, com novos parâmetros de sociabilidade, civilidade e consumo, que deveriam ser almejados e buscados pelos leitores desses periódicos que quisessem ser modernos.

No Brasil da década de 1950, a esfera do visual ${ }^{12}$ estava marcada pela introdução da televisão nas principais capitais, pela reorganização da área da publicidade com a abertura de grandes agências no Brasil, pela renovação das artes plásticas através do concretismo, do neoconcretismo e do abstracionismo das vanguardas artísticas presentes nas Bienais de São Paulo, pela criação de museus de arte como o Masp e dos MAM (RJ e SP), pelas experiências inovadoras da fotografia nos cine foto clubes ${ }^{13}$ e por um novo tipo de cinema produzido fora dos grandes estúdios e sob a influência do neo-realismo italiano (como em Rio $40^{\circ}$ e $O$ grande momento), que expressavam a cidade de um novo ponto de vista.

Deve-se também lembrar da vinda ao Brasil, nos anos 30 e 40 e logo após a Segunda Guerra Mundial, de fotógrafos e artistas imigrantes, que haviam trabalhado em revistas importantes na Europa e que haviam sido formados em uma nova estética. É o caso de Jean Manzon e Pierre Verger, que foram contratados pela revista $O$ Cruzeiro. Eles contribuíram para a uma diagramação e uma nova cultura visual das revistas ilustradas.

O campo fotográfico estava caracterizado pela atuação de batedores de chapas (sujeitos sem formação específica e que fotografavam visando uma circulação doméstica restrita), fotógrafos amadores reunidos no movimento fotoclubista (que realizavam cursos, excursões, exposições, publicavam boletins e estavam comprometidos com uma concepção artística de fotografia) e os profissionais da fotografia (donos de estúdios, funcionários de órgãos públicos e fotógrafos de imprensa). ${ }^{14}$

Na pesquisa sobre a fotorreportagem é importante compreender o circuito de produção, circulação e consumo da fotografia de imprensa como um produto cultural. Devem-se considerar as diferentes variáveis que participam em sua produção: a técnica empregada (tipo de câmara, filme, flash, filtros etc.), a formação do fotógrafo, seu vínculo com a empresa jornalística, a história da empresa produtora, sua organização, o perfil da publicação e as particularidades de editoração (da narrativa construída através de uma sucessão 
de imagens ligadas por títulos, legendas e textos), bem como o público leitor a que a revista se dirige.

O paradigma que predominava na utilização de fotografias nas revistas ilustradas era o da cópia da realidade, como um documento verídico que corroborava a veracidade da interpretação dos fatos abordados. As revistas visavam ensinar uma nova maneira de ver através de fotorreportagens, buscando tanto deleitar quanto cumprir uma tarefa educadora das massas. ${ }^{15}$

Nas revistas ilustradas, várias páginas eram dedicadas à mesma reportagem, o que incluía a utilização de muitas fotografias num arranjo dinâmico, formando uma narrativa em imagens e uma composição mais elaborada e complexa. As fotorreportagens tinham um lugar de destaque no início ou nas páginas centrais da edição, intercaladas com publicidade e outros tipos de mensagem jornalística. Segundo Helouise Costa "a fotorreportagem é uma narrativa que resulta da conjugação de texto e imagem, ou seja, da conjugação de duas estruturas narrativas totalmente distintas e independentes, dentro de uma armação própria realizada pela edição". ${ }^{16}$

No que concerne à técnica, passou-se a utilizar câmeras mais leves (como a Zeiss Icon, a Rolleiflex e a Leica), com filmes flexíveis e flash, que permitiam realizar várias tomadas em uma única saída a campo para a produção das fotorreportagens. As fotos eram reveladas pelos próprios fotógrafos no laboratório da redação da revista. ${ }^{17}$ Havia pautas prévias a cumprir, definidas pelo editor chefe, e o fotógrafo era acompanhado de um repórter que redigia a parte textual da fotorreportagem. Em algumas ocasiões, fotos do arquivo da revista eram reutilizadas para escrever determinada matéria. Em outras, as fotos eram compradas de agências fotográficas independentes, como no caso das matérias sobre política internacional.

De forma geral, as fotorreportagens iniciavam-se com uma fotografia de página inteira ou página dupla, uma 'imagem síntese' do tema, que visava mobilizar emocionalmente o leitor. Compreender a relação entre imagem e texto é importante no sentido de compreender como este disciplina a leitura daquela. O título e uma legenda sobreposta a uma fotografia de grande formato completavam o apelo à atenção do leitor. Seguia-se uma seqüência de cerca de 8 a 12 fotos formando uma narrativa em torno do tema principal. Pequenos textos e subtítulo auxiliavam na urdidura da trama e na construção dessa narrativa visual, direcionando a atenção do leitor para determinados aspectos da realidade abordada nas fotos.

As fotos de duas páginas tinham formato retangular, acompanhando as dimensões da revista aberta, que formava como que uma tela de televisão (re- 
cém-introduzida no Brasil, nos anos 50). Depois, seguia-se uma série de fotografias menores, variando entre meia página e um sexto de página.

No que se refere às representações da cidade nas revistas ilustradas nos anos 50, observa-se que os recortes do espaço, dos temas e das formas de construir a narrativa apontam para um processo de construção de determinados sentidos sociais através de uma nova visualidade urbana.

A Revista do Globo era o periódico quinzenal de maior tiragem no Rio Grande do Sul. Tendo sido criada em 1929, tornara-se um veículo de comunicação influente na imprensa regional, como um projeto gráfico e editorial arrojado para o período. Nos anos 50 a Revista do Globo concorreu com outras revistas de tiragem nacional como O Cruzeiro e Manchete, seguindo o mesmo modelo de fotorreportagens com tom sensacionalista misturadas a entretenimento, artigos literários e vida social.

A Revista do Globo tratava da cidade em 135 dos 256 exemplares consultados na pesquisa, publicados entre 1950 e 1960 . Abordava questões sobre a modernização, as novas formas de sociabilidade, os equipamentos culturais, a segurança, a higienização, a habitação, os transportes e a política municipal. A revista valoriza o processo de modernização e alguns dos problemas urbanos de Porto Alegre. Para esse trabalho considera-se apenas uma pequena amostragem desse todo, no sentido de apontar as imagens fotográficas mais recorrentes na Revista do Globo sobre Porto Alegre no período.

Alguns fotógrafos (dois ou três), contratados da Revista do Globo, produziram o maior número de fotorreportagens nos anos 50: Pedro Flores, ${ }^{18}$ Léo Guerreiro ${ }^{19}$ e Thales de Farias. A partir da década de 1950, os nomes desses fotógrafos começaram a aparecer abaixo do título como co-autores das fotorreportagens. $\mathrm{O}$ trabalho deles era complementado por outros fotógrafos freelancers e pelas imagens recebidas das agências de informação. Sabe-se, porém, que esses fotógrafos também desempenhavam outras atividades profissionais - fotógrafos de órgãos públicos, como as Secretarias de Agricultura e de Educação, por exemplo - , o que os diferenciava dos fotógrafos de outras revistas, como O Cruzeiro e Manchete.

Em 1946, Pedro Flores e Léo Guerreiro participaram da fundação de uma associação de fotógrafos profissionais, e, em 1956, da Associação dos Repórteres Fotográficos e Cinematográficos do Rio Grande do Sul (ARFOC), o que aponta para um processo de organização, profissionalização e valorização social do trabalho do fotógrafo na sociedade local, no bojo de um processo mais geral.

Mas de que forma a fotografia serviu para exprimir as representações das transformações urbanas de Porto Alegre na Revista do Globo? Como as foto- 
grafias sobre a cidade se relacionavam com os textos e estavam inseridas na Revista do Globo? Com base no levantamento feito verificou-se que alguns temas eram recorrentes: modernização dos espaços urbanos (verticalização), novas formas de sociabilidade e problemas urbanos. Alguns exemplos podem ajudar a compreender melhor a construção desse novo padrão de visualidade urbana. Algumas dessas fotorreportagens ocupavam de quatro a sete páginas, outras recebiam destaque com fotografias em página dupla, outras contavam ainda com fotos aéreas da cidade. A grande maioria das fotos era diurna, utilizando-se da luminosidade natural com linhas bem definidas, criando contrastes entre claro e escuro que valorizavam as formas dos prédios acentuando os seus volumes e sua escala monumental. Algumas fotografias apresentavam até três planos, com uma grande profundidade de campo.

$\mathrm{Na}$ fotorreportagem "Porto Alegre cresce para o céu e para o rio", ${ }^{20} \mathrm{com}$ fotos de Thales Farias, o processo de modernização é o tema central, com tomadas fechadas do centro da cidade colocando em destaque os novos edifícios (verticalização), bem como as obras da Avenida Beira-Rio (expansão do perímetro urbano) e da ponte sobre o Guaíba (nova escala de construções e ligação entre o sul rural e o norte urbano do estado), o que é enfatizado pelo título e pelo subtítulo da fotorreportagem: "Construções civis: recorde no Brasil e duas obras grandiosas”. São dez fotos de meia página, com o predo-

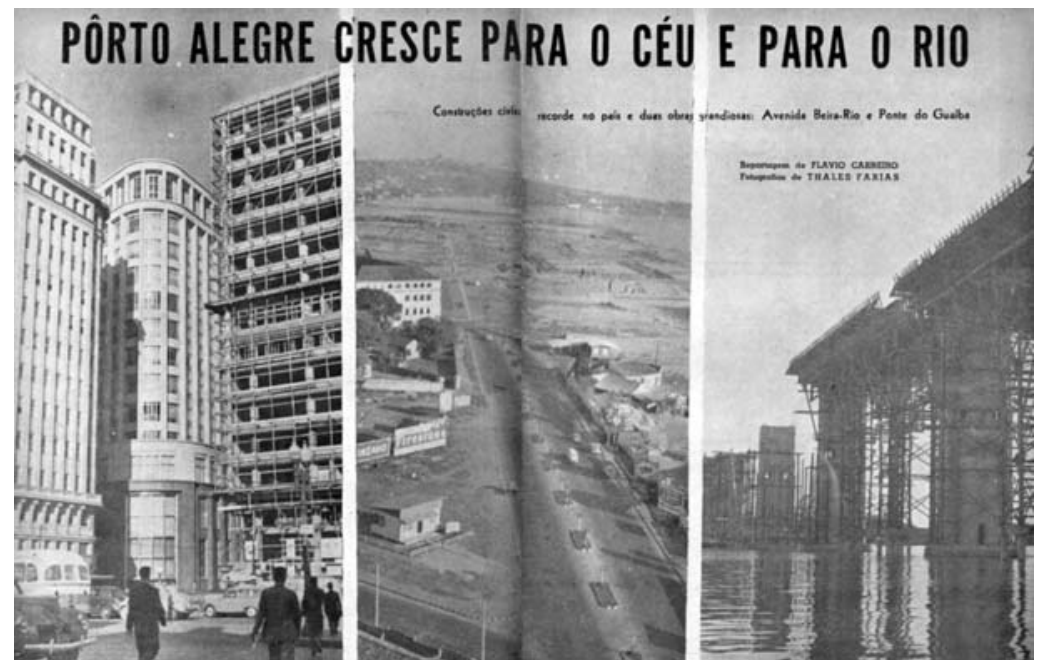

Foto 1 - CARNEIRO, Flávio; FARIAS, Thales. Porto Alegre cresce para o céu e para o rio. Revista do Globo, n.722, 1958, p.38-9. 
mínio do formato retangular vertical. As três fotos que abrem a fotorreportagem apontam para a verticalização, a expansão da área urbana e a monumentalização das construções e obras públicas no espaço urbano. Enfatiza-se a imagem de uma cidade em construção, em movimento, afirmando o significado dinâmico do trabalho e da circulação pela novas avenidas. A presença do leito de ruas ou avenidas em primeiro plano, em quatro fotografias, orienta o caminho do olhar e constrói um padrão de circulação urbana associado ao movimento de automóveis e pessoas. Das dez fotos, nove representam construções inacabadas e uma delas mostra prédios recém-construídos. Linhas bem definidas, contrastes de tons, luminosidade direta e fotos tiradas no sentido ascensional enfatizam os efeitos de verticalização e monumentalidade dos prédios de alto gabarito.

A legenda da terceira página afirma: "Porto Alegre, 1958: recorde brasileiro de construções”. O texto ensaia uma explicação para essa 'febre de construções': "o aumento vertiginoso nada tem de influências políticas, mas é tão-somente a ação de capitais particulares, pois com a desvalorização constante do cruzeiro, o negócio mais rendoso e seguro ainda continua sendo o imobiliário". O dinamismo do processo de transformações do espaço urbano é atribuído ao empreendedorismo de investidores privados e à especulação imobiliária.
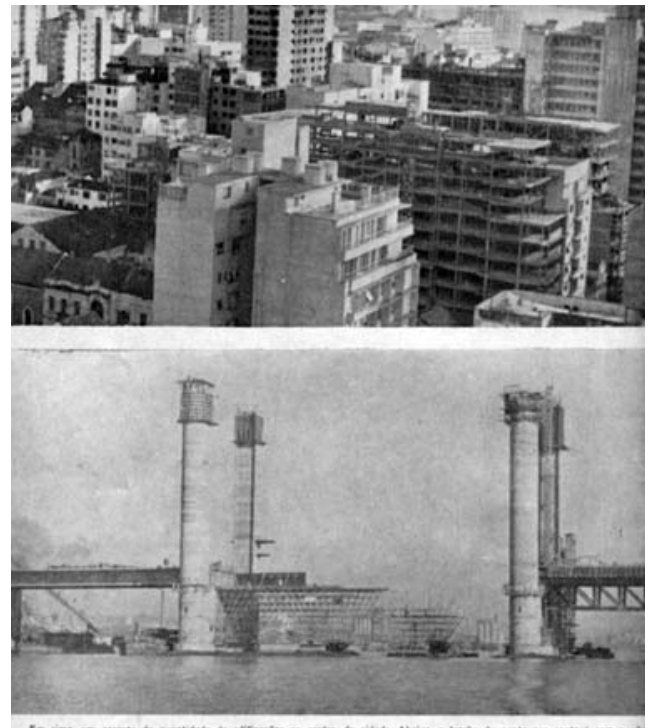

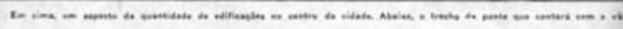

Pôrto Alegre, 1958 - recorde brasileiro de construçōes
Foto 2 - CARNEIRO, Flávio; FARIAS, Thales. Porto Alegre cresce para o céu e para o rio. Revista do Globo, n.722, 1958, p.40. 
Mas talvez o melhor exemplo desse engajamento da Revista do Globo em dar publicidade a tal projeto de modernidade urbana seja a fotorreportagem "Porto Alegre via aérea, 1959", ${ }^{21}$ de sete páginas, com fotos de Thales Farias. Ela está composta por seis fotos, quatro delas de grande formato retangular e duas de um quarto de página. Ela começa com uma foto aérea parcial do centro da cidade, ocupando duas páginas. O sentido diagonal sugerido ao olhar pela foto enfatiza o processo de a verticalização do centro e como que a passagem do passado (representado pelos prédios baixos em primeiro plano) para o presente, representado pelos edifícios de grande gabarito, em segundo plano e destacados pela luminosidade natural. Na página seguinte outra foto área do centro da cidade, com a legenda "dentro de alguns anos, a cidade não terá mais prédios velhos", sugere percurso semelhante para o olhar visando o mesmo efeito. O subtítulo da quinta e da sexta páginas afirma "vistos de cima, os problemas lá de baixo, ficam bem menores", ou seja, as fotos panorâmicas tendem a diluir as contradições entre as diferentes formas de ocupação e a segregação social no espaço urbano.

Mas não há somente publicidade da modernização ou a venda de uma imagem da cidade para consumo dos leitores de classe média na Revista do Globo. Ela também cumpria o papel de apontar os dilemas que a cidade en-

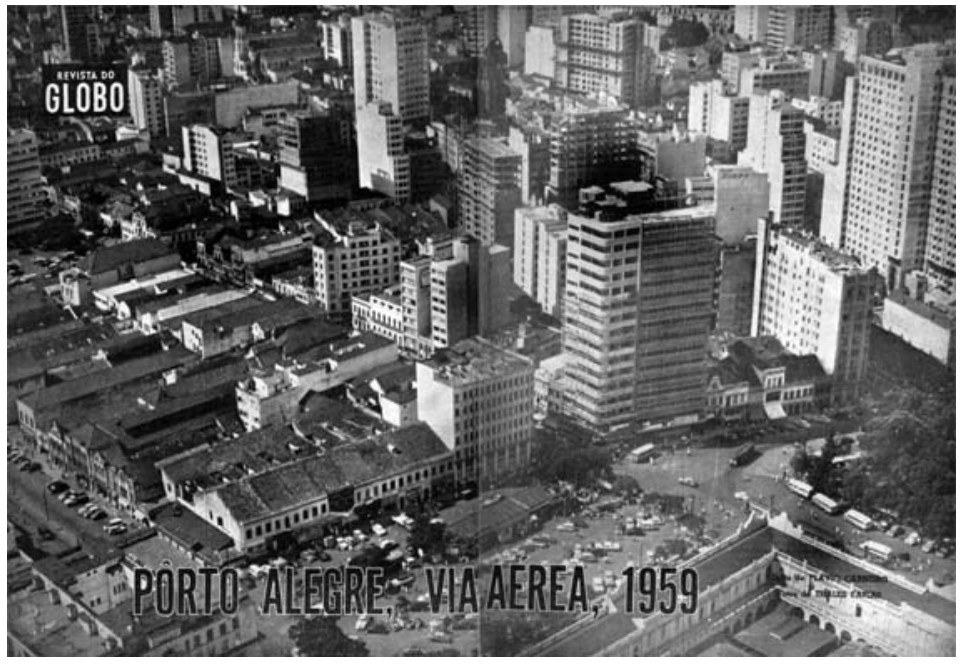

Foto 3 - CARNEIRO, Flávio; FARIAS, T. Porto Alegre via aérea, 1959. Revista do Globo, 1959, n.742, p.10-1. 


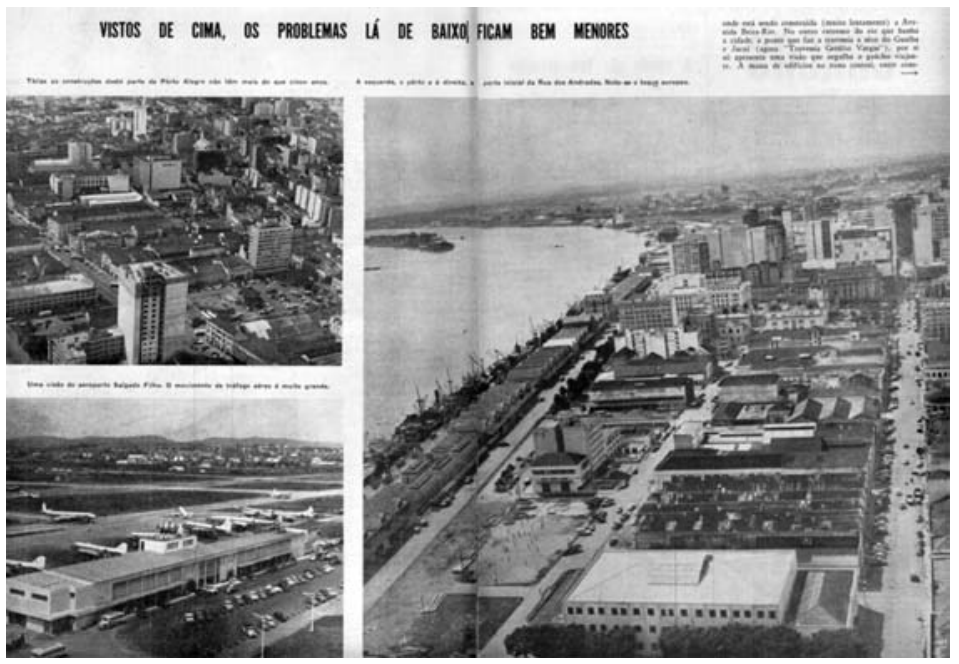

Foto 4 - CARNEIRO, Flávio; FARIAS, T. Porto Alegre via aérea, 1959. Revista do Globo, 1959, n.742, p.14-5.

frentava e deveriam mobilizar a opinião pública e a vontade das administrações municipal e estadual para a sua resolução.

A fotorreportagem "Amarelou o sorriso da cidade", ${ }^{22}$ com texto de Joseph Zukauska e fotos de Pedro Flores e Wilson Cavalheiro, é um exemplo disso. Uma série de 15 fotos, a maioria delas de pequeno formato, apontava os problemas urbanos: falta de água, luz, transportes e moradias. A fotorreportagem inicia-se com uma foto de página inteira, uma vista parcial da área central no sentido descencional em que a maior parte da foto é ocupada por prédios de alto gabarito e prédios em construção. A legenda afirma que "quem a vê assim, cada vez mais alta, não supõe que a cidade se debata numa crise de crescimento" (p.48). Na página seguinte, duas fotos quadradas do um sexto de página apresentam em primeiro plano o problema dos camelôs e das filas de espera de ônibus no centro da cidade, mas em segundo plano e ocupando a maior parte da fotografia estão prédios de alto gabarito, apontando para a construção de significados modernos.

Na quarta página, as fotografias apontam para a contradição entre os altos e modernos edifícios do centro da cidade e as malocas nas vilas populares da periferia de Porto Alegre. Porém, o sentido das fotos sugerido pela leitura da esquerda para a direita parece sugerir a sua superação por obras que estavam em curso na cidade.

Ao final da fotorreportagem, o texto afirma que as razões para essa crise 


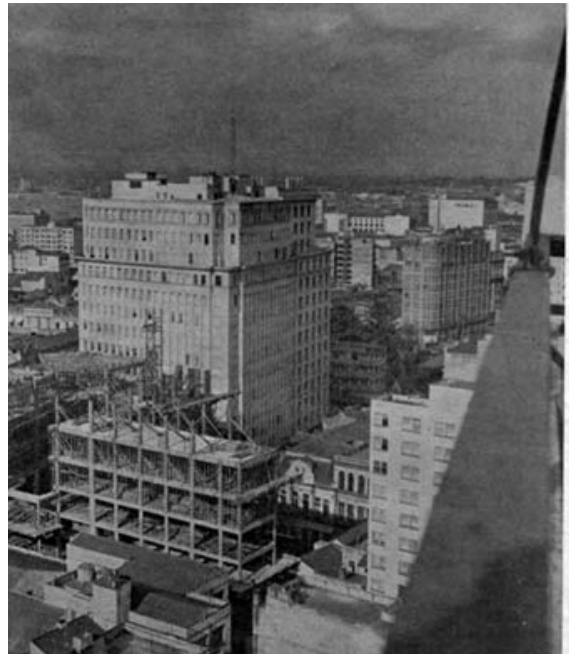

\section{Amarelou o Sorriso da Cidade}

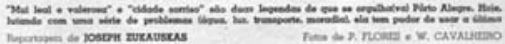

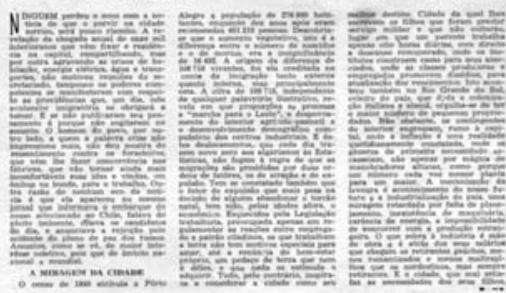

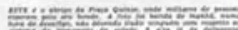
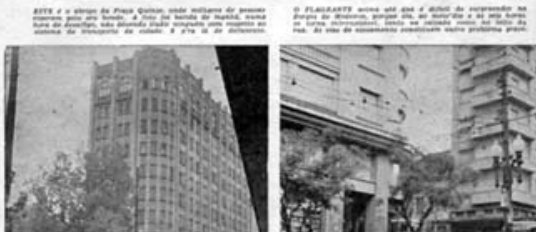

Foto 5 - ZUKAUSKA, Joseph; FLORES, Pedro, CAVALHEIRO, Wilson. Amarelou o sorriso da cidade. Revista do Globo, 1954, n.607, p.48-9.

Uma cidade de zinco e trapos dentro da outra.

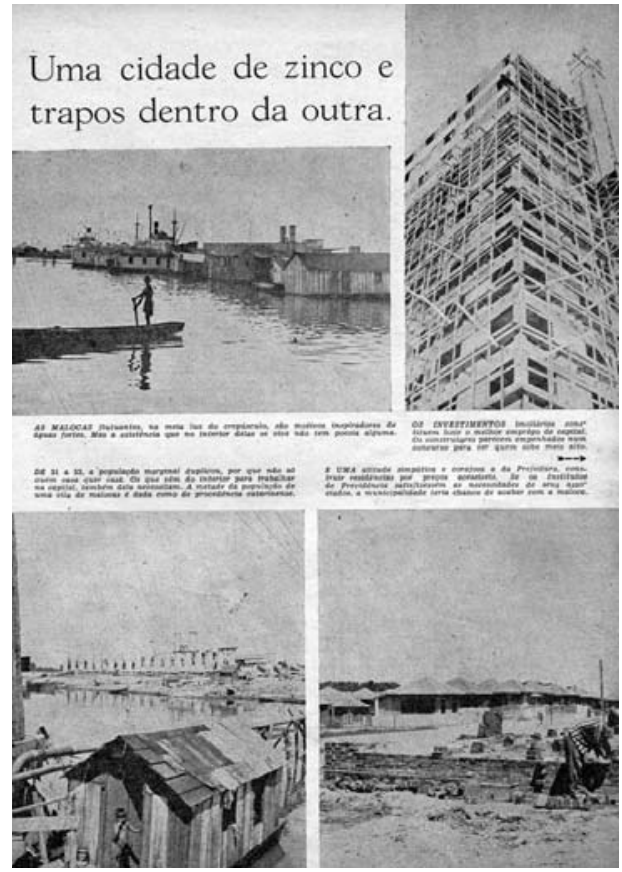

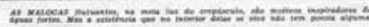

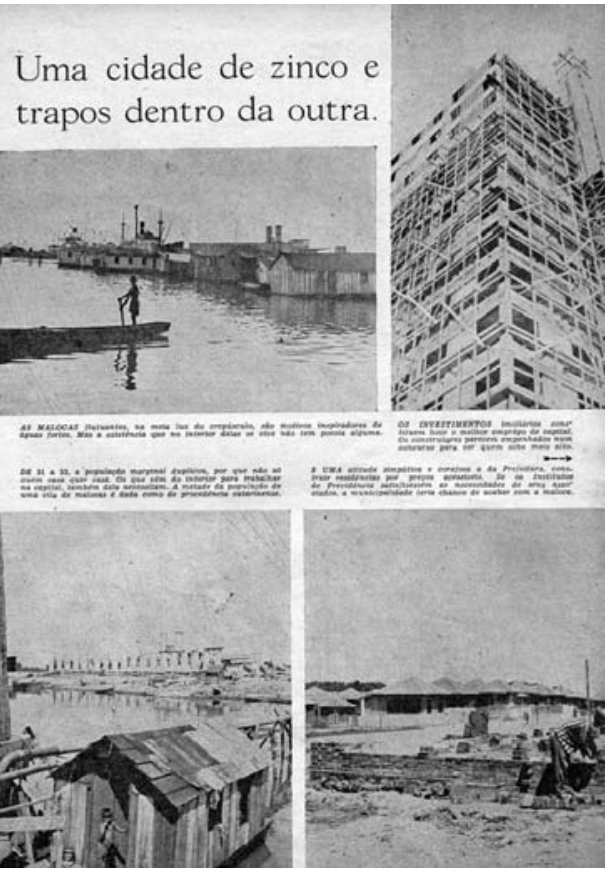

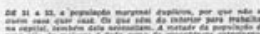

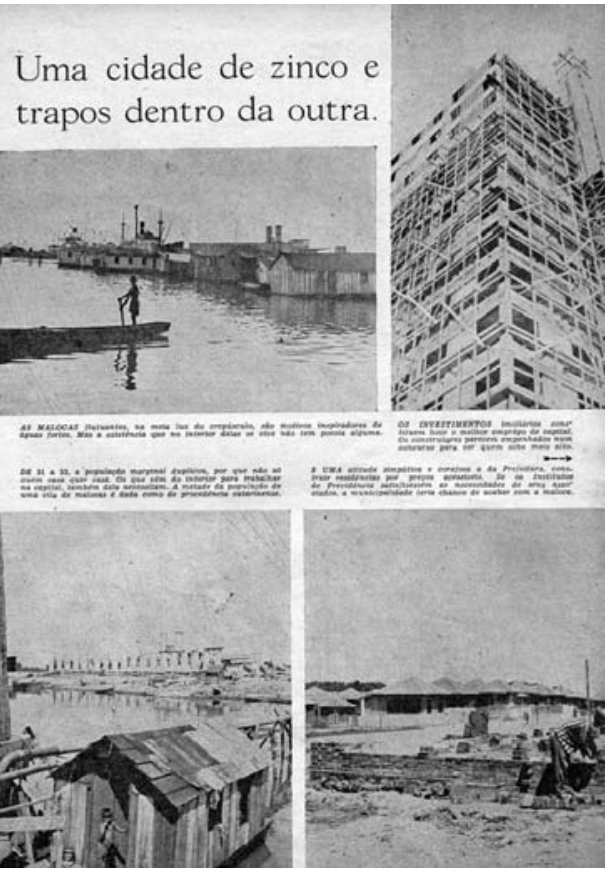

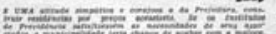

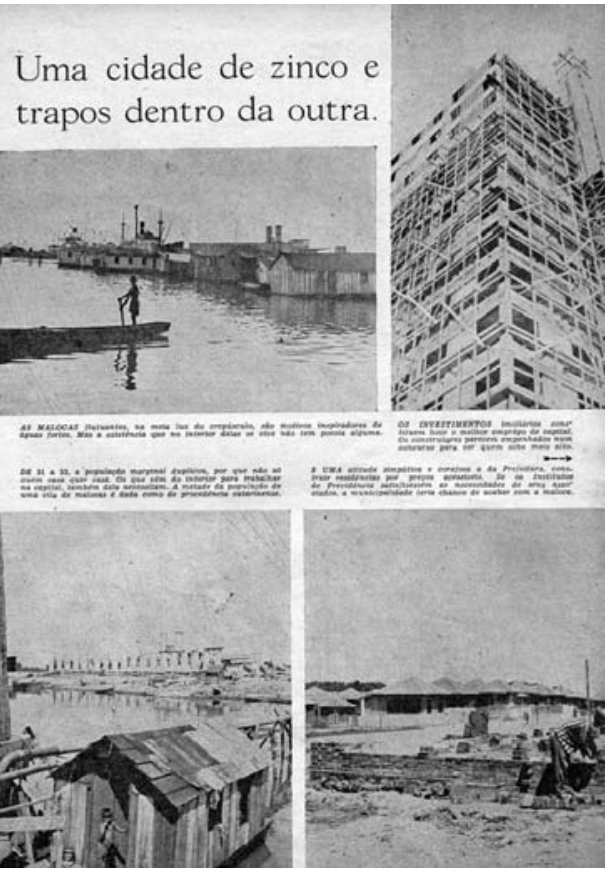

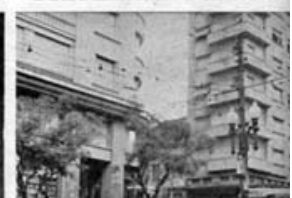

Foto 6 - ZUKAUSKA, Joseph; FLORES, Pedro, CAVALHEIRO, Wilson. Amarelou o sorriso da cidade. Revista do Globo, n.607, 1954, p.51. 
urbana seriam a modernização no campo e a falta de amparo ao trabalhador rural, que agiriam como fatores de expulsão do homem do campo. De outro lado, os motivos de atração de migrantes para a capital seriam a busca de trabalho na indústria, melhores salários, direitos trabalhistas, serviço de saúde e educação para os filhos. Nessa fotorreportagem (p.50), a revista coloca lado a lado um alto edifício em construção e as casas de madeira de uma vila à beira do Guaíba. O subtítulo no alto da página afirma: "Uma cidade de zinco e trapos dentro da outra", e na legenda consta: "De 51 a 53, a população marginal duplicou, porque não só quem casa quer casa. Os que vêm do interior para trabalhar na capital, também dela necessitam. A metade da população de uma vila de malocas é dada como catarinense" (ibidem, p.49). Logo, a culpa dos problemas urbanos era atribuída aos migrantes e que vêm de fora da cidade, às vezes, até mesmo de fora do estado. Ou seja, a culpa era dos não-cidadãos, dos próprios excluídos, e não da falta de planejamento e de políticas públicas adequadas. A questão da moradia precária permite comparar as malocas de Porto Alegre às favelas do Rio de Janeiro e aos mocambos de Recife.

As imagens da casas autoconstruídas são pontuais, descontextualizadas de seu entorno, não permitindo observar nem a dimensão do fenômeno nem localizá-las no tecido urbano da cidade e em sua eventual proximidade da área central. Descontextualização e fragmentação são dois procedimentos usados pelos fotógrafos ao construírem a imagem dos 'problemas urbanos', bem como as panorâmicas que diluem as contradições e a segregação espacial.

Num esforço de síntese, pode-se dizer que o 'espaço geográfico' ${ }^{23}$ destacado é o espaço urbano, o centro, que passa a representar muitas vezes toda a cidade (como numa metonímia), excluindo do quadro fotográfico as vilas e periferias. Por sua vez, as imagens do centro da cidade privilegiam os espaços públicos com ângulos abertos sobre as principais ruas e avenidas, por vezes no sentido ascensional, privilegiando a verticalização dos prédios de alto gabarito, e noutras, descensional, criando panorâmicas que enfatizam a expansão da área central.

O que se destaca no 'espaço dos objetos' são os prédios de alto gabarito, com mais de dez andares, os principais edifícios públicos e privados comerciais e residenciais do centro da cidade e as grandes obras públicas (federais e estaduais). Eles ajudam a construir a percepção de uma nova escala monumental de crescimento e de verticalização, bem como dos novos significados de produtividade urbana. Mas destacam-se também os automóveis, que ajudam a dar uma noção da escala dos edifícios e ajudam a construir significados de modernidade urbana.

O 'espaço de figuração’ é monopolizado pela circulação de carros, ônibus e pessoas no centro, principalmente de homens adultos em idade produ- 
tiva, o que coloca em destaque os significados sociais relativos ao trabalho e ao consumo de bens e serviços urbanos. As pessoas são representadas em vistas parciais do centro, de longe, não permitindo sua identificação individual, em movimento, circulando, trabalhando e comprando. Aponta-se assim para o transeunte anônimo, produtor e consumidor dos espaços, produtos e serviços urbanos. Os prédios de alto gabarito são enquadrados em segundo plano, indicando que essas pessoas vivem, trabalham ou consomem produtos nesses prédios modernos.

O 'espaço de vivência' é o espaço urbano ordenado, planificado, racionalizado e produtivo da cidade moderna com seus fluxos incessantes de trabalho e consumo, com uma nova temporalidade urbana caracterizada pela circulação de pessoas e automóveis no centro da cidade.

Pode-se dividir a década de 1950 em duas metades. Na primeira observa-se a formulação dessa nova visualidade urbana moderna, mas ainda com a presença de imagens das contradições sociais e dos problemas urbanos: falta de habitações e de energia, congestionamento, filas de ônibus, alagamentos, falta de hospitais, de água tratada, de esgotos etc. Na segunda metade dos anos 50 as revistas se engajaram mais no discurso desenvolvimentista de Juscelino Kubitschek, com seus " 50 anos em 5", e passaram a focalizar essencialmente o processo de transformação e modernização da sociedade urbana, deixando para um terceiro plano as críticas e as contradições que acompanhavam esse processo. As revistas ilustradas davam forma à utopia urbana da cidade moderna, planejada, funcional e racional, e buscavam dar corpo a esse projeto de modernidade voltado para o futuro, mas que fincava suas raízes no presente.

A recepção das revistas ilustradas pelos leitores é ainda uma questão que exige mais estudos, ${ }^{24}$ mas temos indícios de sua ampla circulação pelas tiragens divulgadas nos editoriais (nem sempre confiáveis), pelas diversas coleções completas que existem nos arquivos e à venda nos sebos, bem como pelas fotos enviadas por leitores para as revistas em resposta aos concursos promovidos por esses veículos de comunicação.

Pode-se dizer que esse público era formado principalmente pelas elites e pelas camadas médias urbanas, para as quais se vendia um novo modelo de visualidade urbana através das fotorreportagens, e de vida e consumo modernos através da publicidade.

A fotorreportagem era uma nova linguagem, que permitia gerir as imagens mestras e administrar os significados sociais de um país em processo de transformação. A narrativa, que unia fotografias, textos curtos e publicidades nas revistas ilustradas, apontava para um novo tipo de leitor e de leitura no espaço urbano, em uma nova temporalidade marcada pelo automóvel, pelo 
cinema, pelo rádio e pela televisão. Um novo tipo de prática de leitura, mais rápida e dinâmica, mas também mais superficial e menos reflexiva, pois as imagens pareciam dizer 'foi assim que aconteceu', permitindo gerir os novos significados concorrentes e complementares desse processo de modernização.

Como conclusão parcial, pode-se afirmar que a Revista do Globo foi um meio de comunicação que se engajou na modernização da cidade, procurando elaborar esse processo para seus leitores. Nesse sentido, tratou de temas como a verticalização do centro da cidade, a conquista de novas áreas através de aterros, a construção de grandes obras públicas, a implantação dos novos padrões arquitetônicos modernistas, bem como a modernização das formas de sociabilidade pública numa sociedade de consumo. Quando a revista apontava os problemas urbanos de falta de água, energia e habitação, pedia providências aos poderes públicos. As casas populares aparecem em imagens com ângulos fechados, descontextualizadas da cidade, e os bairros populares não são temas de fotorreportagens. Tudo aquilo que não combina com os significados de uma cultura urbana moderna tende a ficar de fora do quadro fotográfico, com os trabalhadores informais, as carroças e os bairros pobres, periféricos ou mais centrais.

Percebe-se que as revistas ilustradas estavam claramente engajadas no projeto político das elites dirigentes de modernização social. O estudo de caso sobre a forma como a Revista do Globo publicava fotografias panorâmicas do centro da cidade com planos fechados sobre as áreas mais centrais de Porto Alegre permite dizer que ela construía um ideário de modernidade urbana. Enquanto os textos difundiam todo um conjunto de idéias e valores que visavam educar as camadas médias urbanas, as principais consumidoras da Revista, para a concretização da utopia da cidade moderna numa verdadeira pedagogia social, as imagens fotográficas elaboravam esse processo veloz de mudanças e desenraizamento social de uma forma positiva.

\section{NOTAS}

${ }^{1}$ Doutor em História Social (PUC-SP), professor adjunto do Programa de Pós-Graduação em História da PUC-RS e vice-coordenador do Centro de Pesquisa em Imagem e Som (CPIS/PPGH/PUC-RS). Esta pesquisa recebe apoio do CNPq (Edital Universal 2006) e da PUC-RS.

${ }^{2}$ Essa definição é próxima daquela oferecida por FLUSSER, Vilém. Filosofia da caixa preta. Ensaios para uma futura filosofia da fotografia. Rio de Janeiro: Relume-Dumará, 2002.

${ }^{3}$ DUBOIS, P. O ato fotográfico e outros ensaios. 5.ed. Campinas (SP): Papirus, 1993. p.61. 
${ }^{4}$ SCHAEFFER, Jean-Marie. A imagem precária. Sobre o dispositivo fotográfico. Campinas (SP): Papirus, 1996.

${ }^{5}$ BARTHES, Roland. A mensagem fotográfica. In: BARTHES, R. O óbvio e o obtuso. Ensaios críticos III. Rio de Janeiro: Nova Fronteira, 1982. p.11.

${ }^{6}$ Em São Paulo, temos o relato autobiográfico da favelada Carolina Maria de Jesus em Quarto de despejo (1960). Essa catadora de papel, ferro e outros materiais vivia na Favela do Canindé, onde faltava água, esgoto e iluminação. Ela foi descoberta pelo jornalista Audálio Dantas, que cobria a inauguração pela prefeitura de um playground para as crianças e resolveu publicar seus escritos acumulados em 35 cadernos velhos e em folhas soltas que ela encontrava pela rua. O título vem da comparação entre a favela e o quarto de despejo da casa, para onde vão as coisas velhas que não servem mais e ninguém quer. Também os sambas de Adoniran Barbosa, como "Despejo lá na favela”, falam na construção de novos edifícios, que exigia a remoção dos barracos, bem como das leis que favoreciam a expulsão dos favelados e sua segregação espacial.

${ }^{7}$ Cf. MUNTEAL, Osvaldo; GRANDI, Larissa. A imprensa na história do Brasil. Fotojornalismo no século XX. Rio de Janeiro: PUC-RJ, 2005; COSTA, Helouise. Aprenda a ver as coisas: fotojornalismo e modernidade na revista O Cruzeiro. Dissertação (Mestrado em Comunicação) - Escola de Comunicação e Artes Visuais, Universidade de São Paulo, 1992, p.53-4.

${ }^{8}$ FREUND, Gisèle. La fotografia como documento social. 8.ed. Barcelona: GG MassMedia, 1999.

${ }^{9}$ COSTA, Helouise. Aprenda a ver as coisas..., 1992, cit.

${ }^{10}$ Cf. BAITZ, Rafael. Um continente em foco: a imagem fotográfica da América Latina nas revistas semanais brasileiras (1954-1964). São Paulo: Humanistas/FFLCH/USP, 2003; COSTA, Helouise. Aprenda a ver as coisas..., 1992, cit..

${ }^{11}$ Assim como os álbuns fotográficos editados nos anos 50 e por ocasião do IV Centenário de São Paulo estudados por Vânia Carneiro de Carvalho, que inspirou várias das reflexões aqui presentes sobre as fotografias de cidade no período. Cf. LIMA, Solange Ferraz de; CARVALHO, Vânia Carneiro de. Fotografia e cidade: da razão urbana à lógica de consumo. Álbuns de São Paulo (1887-1954). Campinas (SP): Mercado das Letras; São Paulo: Fapesp, 1997.

${ }^{12}$ MENEZES, Ulpiano T. Bezerra de. Rumo a uma "história visual". In: Martins, J. S.; ECKERT, C.; NOVAES, S. C. (Org.) O imaginário e o poético nas ciências sociais. Bauru (SP): Edusc, 2005. p.33-56.

${ }^{13}$ COSTA, Helouise; SILVA, Renato Rodrigues da. Fotografia moderna no Brasil. 2.ed. São Paulo: Cosac-Naify, 2004. Houve uma renovação da linguagem fotográfica em curso em espaços de produção fotográfica como o Foto-Cine Clube Bandeirante, nos salões de arte fotográfica e no boletim do Foto-Cine Clube Bandeirante. Fotoclubes congêneres existiam em Porto Alegre, Recife, Belo Horizonte e outras grandes cidades.

${ }^{14}$ Essa organização do espaço fotográfico é sugerida em Cf. MAUAD, A. M. Na mira do olhar: um exercício de análise da fotografia nas revistas ilustradas cariocas, na primeira 
metade do século XX. In: Anais do Museu Paulista, São Paulo: USP, v.13, jan.-jun., n.1, 2005, p.133-74.

${ }^{15}$ COSTA, Helouise. Aprenda a ver as coisas..., 1992, cit., p.65.

${ }^{16}$ Ibidem, p.83.

${ }^{17}$ Transcrição da primeira entrevista com Flávio Damm para o Projeto História do Fotojornalismo Brasileiro, realizada por Ana Maria Mauad no dia 24.042003 (Acervo LABHOI/UFF). Flávio Silveira Damm (Porto Alegre, RS, 1928) começou como auxiliar de laboratório do fotógrafo alemão Ed Keffel, que se refugiou do nazismo em Porto Alegre (RS), durante a Segunda Guerra Mundial; passando a fotografar para a Revista do Globo, em 1946. Obteve a consagração profissional no ano seguinte, ao realizar as primeiras fotografias de Getúlio Vargas em sua fazenda, após o afastamento da presidência da República, o que lhe valeu um convite para integrar a equipe da revista O Cruzeiro, no Rio de Janeiro. Trabalhando nessa publicação durante uma década e meia, celebrizou-se como um dos mais importantes fotojornalistas brasileiros; tendo ainda papel importante como um dos fundadores (com José Medeiros), da agência fotográfica Imagem, em 1962, uma das primeiras do gênero no país.

${ }^{18}$ O fotógrafo Pedro Flores nasceu em Venâncio Aires em 1925. Tomou gosto pela profissão quando vendia fotos em Porto Alegre. Trabalhou em diversos jornais como o Correio do Povo e o Diário de Notícias. Foi fotógrafo da Secretaria de Agricultura e, durante três mandatos, do Setor de Imprensa do Palácio Piratini. Faleceu em 2005 em Porto Alegre.

${ }^{19}$ Léo Guerreiro, nascido em Porto Alegre em 1929, está completando 50 anos como fotógrafo profissional. Entre 1956 e 1969 foi assistente técnico da Secretaria do Estado de Cultura, de onde saiu para lecionar na Universidade Federal de Santa Maria. Lá, criou a disciplina de Fotografia, no Centro de Artes. Continua fotografando, além de trabalhar com restauração manual de fotografias.

${ }^{20}$ CARNEIRO, Flávio; FARIAS, Thales. Porto Alegre cresce para o céu e para o rio. Revista do Globo, n.722, 1958, p.38-42.

${ }^{21}$ CARNEIRO, Flávio; FARIAS, T. Porto Alegre via aérea, 1959. In: Revista do Globo, 1959, n.742, p.10-6.

${ }^{22}$ ZUKAUSKA, Joseph; FLORES, Pedro, CAVALHEIRO, Wilson. Amarelou o sorriso da cidade. Revista do Globo, n.607, 1954, p.48-55.

${ }^{23}$ Para os fins deste artigo fiz uma adaptação da metodologia proposta por Ana Maria Mauad em seu estudo sobre as revistas ilustradas do Rio de Janeiro (Careta e O Cruzeiro) na primeira metade do século XX. Cf. MAUAD, Ana Maria. Na mira do olhar..., 2005, cit.

${ }^{24}$ Sobre a experiência de leitura da revista O Cruzeiro, ver: BARBOSA, Marialva. O Cruzeiro: revista síntese de uma época da história da imprensa brasileira. In: Ciberlegenda, Rio de Janeiro, n.7, 2002. Disponível em: www.uff.br/mestcii/marial6.htm. Acesso em: 14.10.06. 